Curiosity Killed by SATs: An investigation of mathematics lessons within an English primary school

\title{
*Gavin Ward
}

Institute of Sport and Human Performance, University of Wolverhampton, United Kingdom.

Mikael Quennerstedt

School of Health Sciences, Örebro University, Sweden.

*corresponding author and research conducted via this institution

Gavin.Ward@wlv.ac.uk

University of Wolverhampton, Institute of Sport and Human Performance, Walsall Campus, Gorway Road, Walsall, WS1 3BD, UK. 


\begin{abstract}
By taking both pupils' and teachers' actions as the point of departure, this study aimed to understand governance within a primary school classroom. Video footage was recorded in an English primary school in which mathematics happened to be the focus. This data was analysed to identify the directions of both governance and self-governance and to help understand the consequences for pupil and teacher subjectivities. Our findings revealed the central role of national testing and inspection policy in constituting staff as 'evidence hunters' and pupils as 'confessant and unafraid producers of evidence'. Both were complicit in creating sufficient space for everyone to fulfil their obligation to be accountable to the school's senior leadership team, school inspectors and national attainment tests. As a consequence, mathematical knowing was simplified into a discipline of reproducing testable calculation, in which other possibilities of mathematical knowing were foreclosed.
\end{abstract}

\title{
Introduction
}

Testing and inspection are common features of primary education across the globe. In Western Europe, education systems have employed national tests to identify both standards of pupil achievement and school effectiveness (Alexander, 2011). In England these measures form the central framework of the political management of primary schools (Segal, Snell and Lefstein, 2016). This framework aims to build a market lead approach to the provision of education within which schools compete to demonstrate their ability to meet and exceed government standards for teaching and attainment. In this educational market place performing schools survive and attract more pupils whilst those failing to meet the required standards are closed or re-opened under new management and governance. These government standards are primarily based upon pupils' performance within a narrow range of subject specific skills. Ball (2013) has argued such a system of provision is mechanistic and founded upon compliance and standardisation. Whilst providing political control, Ball (2013) states that differences in test scores and inspection ratings merely reflect inequalities between schools in relation to levels of parental support, housing quality and household income (Burnitt, 2016). Boaler (2015) contend that rather than being diagnostic, such high stake testing obstructs the fostering of pupils' inquisitiveness and curiosity via pedagogical creativity and innovation.

In English primary school pupils complete national tests in mathematics and English. Thee subject form part of 'core' national curriculum subjects. Understanding the relationships between tests in these core subjects and the classroom has been an ongoing interest to researchers. For example, studies have helped us to understand how specific teaching approaches can support pupil performance, or how testing can hinder pupils from specific sociocultural groups (Richards, 2008). It has also become clear how testing narrows school curricula, pedagogy and professionalism (Ball, 2013). In this paper, we build on Ball's (2013) claims regarding teaching as a quantifiable performance. Using this position we set out to understand the relations between the prevailing policy landscape of national testing and inspection in England and governance within a primary school classroom. Video footage was recorded, in which mathematics happened to be the focus. This data was analysed by taking both pupils' and staff actions as the point of departure. During our 
analysis we attempted to identify the directions of both governance and self-governance to help understand the consequences for pupil and teacher subjectivities. In doing so, we aimed to explore what teachers and pupils 'became' within their negotiation of the directions of governance and self-governance.

This paper first provides a brief discussion of research which has explored some of the consequences of national testing and inspection within English primary schools. We then locate our decision to use Foucault's theorising of governance and self-governance as our research tool within the field of school mathematics research. This positioning of our research and an exploration of what is already known about pupil and teacher subjectivities with primary school mathematics, is then employed to generate our research questions. We then explain our methodological considerations which are followed by a discussion of our findings and final conclusions.

\section{Primary school governance in England}

Since the 1980s schools in successive governments England have sought to develop a marketised approach to educational provision. Within this market measurement of 'effectiveness' is linked to the performance of pupils in national assessments. These form a combination of teacher assessments and national Standard Assessment Tests (SATs) which occur in primary schools at the end of each Key Stage (KS) of schooling (KS1; ages 5-7, KS2; ages 7-11). These modes of assessment are often referred to as 'high stakes' as pupils' performances determine whether or not a school is 'failing', 'coasting' or 'requires improvement' (Segal, Snell and Lefstein, 2016). Judgements of this kind are governed by inspections made by the Office for Standards in Education (OfSTED) who require all schools to demonstrate how SATs results are used for internal monitoring of teaching standards (Ozga, 2009). This monitoring process is supported through data analysis tools provided by RAISEonline which tracks historical pupil performances across the curriculum. SAT results are available publicly online via the Department of Education and are used as measures of school effectiveness in regional and national league tables (DfE, 2017).

Research has consistently raised concern about the tensions created through these external measures of accountability, in particular, how prescription and standardisation of practices challenge teacher's autonomy and professionalism (Keddie, 2017). Performance targets and public judgement have come to regulate ways of working that compel teachers to compete within the market place of education (Wilkins, 2015). According to Keddie (2017) such regimes of governance imply professional mistrust and narrow what constitutes as desirable educational outcomes. The need to produce performing pupils results in pedagogy directed towards a 'teach-to-the-test mentality' (Keddie, 2017; p.7) orienting schools to teach pupils 'what' to think rather than allowing space to enable them to teach 'how' to think. According to Connell (2009) governing schools in this way concurrently reduces the opportunity for teachers to critique the parameters by which they are being governed, yet, makes them the key component of the system. 
Evidence suggests that standards-based reforms, direct accountability and marketisation, strengthen particular pedagogical practices (Boaler, 2015; Segal, Snell and Lefstein, 2016). Hill, et al. (2016) for example, report how this context creates significant tensions for teachers particularly in relation to surveillance, micro-management and control of everyday practices. Bob (2002) has explored the tensions created when primary school teachers' humanistic commitment to education clash with performativity discourses. He suggests governance through testing has diminished mutual relations between teachers and pupils, creating more distant ties of pupil dependency. This change is also evident in how teachers function together, challenging relations of consensus by marginalising individuality and creating stratified and self-disciplining teams (Bob, 2002). More recently, Burnitt (2016) has examined potential resistance to this dictatorship of assessment data by exploring the desire for primary school headteachers to return to more balanced and creative curricula. This resistance to management by assessment data was powered by the headteachers' beliefs that assessment data simply reflected inequalities between schools in levels of parental support, housing quality and household income.

Driving schools to be productive, to add value and to be economically efficient has particular consequences for pedagogical relations within the classroom. According to Ball (2003) this has made 'old ways of thinking and relating dated, or redundant or even obstructive' (p.218). The language of business has fuelled discourses which are altering the discursive landscape of pedagogical relation; the construction of teaching and learning, relationships between the learner, learning and what is constituted as knowledge. By utilising the tools that Foucauldian theorising offers, Ball $(2003 ; 2013)$ has employed his extensive analysis of this discursive landscape to theorise the notion of teacher 'performativity'. He argues external monitoring and standardised testing has constituted teaching into a quantifiable performance. As a result this changes what learning 'is', how it is 'done' and 'who' teachers are supposed to be. Through governance, mechanisms such as performance management, create a direct line of accountability and increase perceptions of vulnerability. As a result, Ball (2003) concludes teachers not only teach to the test, they also 'perform to the test' by abandoning personal values about education in order to ensure job-security.

More recently, Ball (2013) has endeavoured to rewrite educational policy as 'a history of practices, and truths and subjects, and relations of power and government' (p.153). Such work illustrates how Foucauldian theorising enables the researcher to explore the embodiment of discipline and regulation within education discourses. Ball (2013) explores how national testing, school standards and inclusion, actually divide and shape the flesh and blood of those whose lives it aims to change. Within the classroom, teachers have to negotiate pressure to ensure their pupils are prepared to perform in high stakes assessments, while at the same time negotiate their own political positions in relation to these pressures (Pais, 2016). This requires teachers to become particular people but also children to negotiate particular ways of being a pupil (Booher-Jennings, 2008; Hardy and Lewis, 2016; Teague, 2014). 


\section{Researching subjectivies within mathematical education}

Contemporary theorising of teachers' and pupils' within mathematical education has aimed to better understand the relations between mathematics as subject-matter and the social worlds of learning with school classrooms (Ernest, 2016). Much of this important work focusses upon exploring policy and the perspectives of secondary aged pupils and their teachers. Some researchers, for example, have aimed to consider the construction and reproduction of gender through the teaching of mathematics (Epstein, Mendick and Moreau, 2010; Llewellyn, 2009; Walkerdine, 1989; 1999). Other authors such as Kollosche (2014), have focussed upon the subject-matter of mathematics, in particular, how logic and calculation reproduce particular world views. Such theorising aims to move away from the psychological individualisation of mathematical education, in order to position the subject as a function of the "community that embraces it and evolves in relation to the needs expressed and tasks performed" (Brown, 2008; p.243). As a result, debate with mathematical research has moved towards a more detailed analysis of measures of mathematical achievement in schools in which pupils and teachers are shoehorned into restrictive practices (Clements, et al., 2013). Walshaw (2013), for example, questions what is validated and privileged within mathematical pedagogical practice when teachers negotiate what are identified as systemically oppressive conditions. Clements, et al., (2013) suggest these conditions arise from the conflict between the policy outcome of producing a 'numerate' population and the educational exploration of the wider possibilities for mathematics to support logical thinking.

Within these difficulties and tensions, Llewellyn (2016) identifies a conflicting separation between the construction of the mathematical child within government policy and the theorising of the child with mathematical education. By using Foucauldian theorising to consider how 'progress' is constructed within policy and research, Llewellyn (2016) exposes the disparities between the 'romantic' and 'naturally' developing child of research, and the logical 'linear' mathematical progress expected by policy. It is the ambition of this study to contribute to the exploration of these tensions between policy and the teaching of mathematics. By taking actions within a primary school classroom as a point of departure, we set out to understand the mutual construction of both teachers' and pupils' subjectivities. By capitalising upon the promise shown through the use of Foucauldian theorising, this study aims to bring both the macro context of educational policy and micro context of classroom pedagogic relations into view.

Rather than providing a theory of society, Foucault claimed that he produced 'tools' to be used to investigate the mechanisms, negotiation and consequences of power relations (Foucault, 1977/1995, p. 205). Within education, Foucault's metaphor of the panoptic prison tower has been employed to locate how surveillance and self-surveillance work to govern the practices of schools (e.g. Azzarito, 2009; Blackford, 2004; Perryman, 2006, 2009).

Historically, inspection regimes and testing have been identified across the globe as particular techniques of governance and self-governance within schools (e.g. Lingard, Martino and Rezai-Rashti, 2013; Webb, et al., 2009). However, Gallagher (2010) suggests that all too often in educational research the panoptic metaphor has been taken too literally and has sought to prove its existence. With this critique in mind, we set out to use the panoptic 
metaphor to explore the relations between a policy landscape dominated by testing and inspection and the mechanisms of governance and self-governance within everyday actions in a primary school classroom. By identifying how governance and self-governance are realised we also aim to discuss both teacher and pupil subjectivities. To guide this process we posed three research questions:

- What constitutes mechanisms of governance and self-governance?

- What direction does this governance take?

- What pupil and teacher subjectivities are created in this process?

\section{Methodological considerations}

In Foucauldian theorising power is contained within the everyday practices of life. Subjects do not stand outside of power but act from within its constraints and are thus relational to power (Biesta, 2008; Rabinow, 1984). For Foucault subjects can be constituted through control and dependence or can also be tied to their own identity through conscience or self-knowledge (Foucault, 1982; p.781). These conceptions of subjectivity theorise power as subjugating and an implicit part the subject. For Foucault subjectivity is about choice of actions within the power relations of particular historical contexts. It is different power relations and actions that constitute individuals as subjects (Foucault, 1987). According to Gallagher (2010) and Courtney (2016; p.623) many investigations within education simply 'confirm' the existence of Foucault's 'panoptic' metaphor within the discourses of governance such as inspection and testing. Rather than risk reproducing such work, this study employs the panoptic metaphor of governance as a means to reveal the co-constituting subjectivities created within a primary classroom. Governance requires disciplinary power and in this way the individual as both the object and instrument of its exercise become the concern. The individual becomes the object, because disciplinary power aims to produce particular subjectivities. These choices and actions become the instrument of governance by creating a system of self-surveillance, in which the individual 'polices' his or her own actions (Foucault, 1977/1995).

\section{Panopticism}

Foucault's panoptic or 'all seeing' metaphor was based upon a prison design developed by Jeremy Bentham in 1791. Although it was never fully realised in practice, Bentham's design aimed to develop complete control of prisoners by individualising them and creating an ever-present system of surveillance. This was to be achieved by arranging individual prison cells around a central inspection tower. Through lighting and window design prisoners within the cells were on constant view to guards stationed within the tower. However, while the prisoners were on view, the guards were not and thus could 'see' without 'being seen'. Foucault (1977/1995) employed this proposed system to demonstrate how systems of governance aim to create continual visibility. Constant surveillance works to make the individual consciously visible, to be known and judged so that they assume responsibility for the constraints of power "he makes them play spontaneously upon himself; he inscribes in himself the power relation in which he simultaneously plays both roles; he becomes the principle of his own subjection" (Foucault, 1977; p.202-203). Thus, continual presence of 
the gaze of power promotes self-surveillance, which Rose (1998) argues, becomes grounded in norms and claims of truth. These mechanisms of direct and self-governance have become part of everyday life in western societies and part of the 'DNA' of social institutions such as schools (Ball, 2013). Elden (2003) suggests that rather than using the panoptic metaphor as a basic model of power with which to draw comparisons, we should see it as a culmination of disciplinary power within institutions. In response, we follow Gallagher's (2010) belief that Panopticism is something researchers should aim to move beyond. It is our ambition to analyse how mechanisms of power work to normalise subjectivities. In analysing how these evolve and in what directions, it is our intention to identify how staff and pupils negotiate these identified mechanisms of power.

Resistance to mechanisms of power occurs as a matter of course and is therefore viewed as a necessary precondition for power (Teague, 2014). Power relations are thus a manifestation of the interconnections between power and resistance. In Foucauldian theorising these interconnections make power integral to action. As Foucault (1982) explains, power is:

a set of actions on possible actions; it incites, it induces, it seduces, it makes easier or more difficult; it releases or contrives, makes more probable or less; in the extreme, it constrains or forbids absolutely, but it is always a way of acting upon one or more acting subjects by virtue of their acting or being capable of action. A set of actions upon other actions. (p. 789)

Power can limit actions but also create possibilities of action by building upon the action of others. By using Foucault's work in this way, we hope to be able to say something not only about the mechanisms of power but additionally what is produced through staff and pupil's negotiation of these mechanisms. By looking at the directions of these actions we can discuss what both the staff and pupils 'become' within the governance of the classroom.

\section{Ethical considerations}

Data for the study was collected using an observational case study (Öhman \& Quennerstedt, 2012). Video-recordings were made of an opportunistic sample (Bryman, 2008) of a mixed class of Year 5 and 6 pupils, aged between 10-11 years, within a state maintained primary school. This was an average sized school of approximately 320 pupils aged 3-11 with a low free school meal uptake in England. By using video film, our aim was to take everyday actions on actions of staff and pupils as the point of departure for analysis, capturing spoken words, gestures and movements as actions on the action of others.

Gathering data in this way required careful consideration before ethical approval was sought and granted by a University Ethics Committee. Particular attention was made to the process of seeking consent, the introduction of video cameras into the classroom and the 'ethically important moments' encountered when filming staff and pupils (McEvoy, Enright and MacPhail, 2015). Sensitivity was paid to adult-child and teacher-researcher power relations and decisions to agree to be involved (Robson, 2011). No child declined to be involved in the study, however, one support assistant requested not to be filmed. Great attention was paid to ensuring this member of staff was not deliberately filmed or featured in any background of 
the footage. This was aided by their specific involvement in one particular child and thus their positioning in the classroom was predictable.

Despite phasing in filming and encouraging pupils to record and view themselves on film (Robson, 2011), as with all research, 'ethical moments' arose when, for example, children or staff members decided that at a particular time they were reluctant to be filmed (McEvoy, Enright and MacPhail, 2015). This was signalled by gesture, look or verbal request. This communication was fully respected and participants were not deliberately selected to be in shot. In some cases, filming had to stop. Additional incidents, such as when children wanted to share their work or requested support specifically from the researcher, filming also had to halt to accommodate these requests. In being sensitive to the participants and the purpose of the study, the aim was to recognise and manage the ethical decision making required to limit the intrusiveness of the filming (Puurveen, et al., 2015; Whiting, et al., 2016). By working in this way the researcher was required to continually mediate between being a trusted observer and member of the classroom.

\section{Data analysis}

Whilst approximately 10 hours of film was collected over a period of 5 weeks, a complete account cannot be claimed to be gathered. In managing the ethical considerations required in such a study our video-recordings can only produce selective data (Öhman \& Quennerstedt, 2012). This data provides examples of the lessons that happened to be taught at the time the member of the research team was able to visit the school. In this study data collection occurred in the mornings of one or two days a week within the autumn term. Within this time we were able to observe the school's dedicated time for 'numeracy', in which teaching was focussed solely upon the subject of mathematics. The focus of this study was thus privileged, rather than any preselected area of the primary curriculum.

We initially followed an abductive process in the analysis of our data by employing the panoptic metaphor to understand the focus and directions of actions (Tavory and Timmermans, 2014). These materialised from the uses and purposes of objects, instructions, tasks and topics of discussion. By working abductively back and forth between the films, our research questions and the panoptic metaphor, we developed the following questions to help drive our analysis:

- How is governance and self-governance materialised through instructions, tasks, etc.?

- What are the relations between the objectives of this governance and selfgovernance and testing/inspection?

- How, and by whom, is the direction of this governance and self-governance negotiated?

- What subjectivity does this negotiation create through this process of negotiation?

We initially set out to identify the main mechanisms of governance and selfgovernance. By identifying what was being negotiated and resisted, we were then able to 
concurrently identify the directions of this governance and self-governance. Each segment of film was watched in its entirety and initial notes were developed to catalogue the segment in relation to the mechanisms and direction of the governance and self-governance observed. Using our analytical questions these categories were then reviewed and developed into potential themes. Corresponding segments of film were then selected for further in-depth analysis. These segments were transcribed and located within a matrix in order to confirm and refine our identification of the mechanisms and directions of the governance and selfgovernance. In the next section of this paper we present our identified themes and directions of governance. We then use these results to discuss our identification of pupil and teacher subjectivities; Staff as evidence hunters and Pupils as a confessant and unafraid producers of evidence. By completing this process we are then in a position to consider the pupil and teacher subjectivities created.

\section{Findings}

The numeracy lessons observed usually occupied the majority of the morning's activities. This was divided into two sessions by a 15 minute break. The children sat at desks in pairs and also in larger groups of 6, with all chairs facing an electronic, and a standard, whiteboard. The walls of the classroom displayed a rich and busy mixture of the children's work, pupil achievements and subject specific information such as calculation and grammatical rules. In one corner of the room there was a very small back room, sectioned off by a curtain which was able to squeeze in an adult and up to 6 pupils. The lessons were led by the class teacher and supported by two Learning Support Assistants (LSAs). One of the LSAs was the dedicated support for a specific pupil. This child was mostly taken elsewhere in the school by the LSA for numeracy. The other support assistant worked with various groups either in the classroom or in the little side room. Like the teacher, this member of staff had responsibility to mark pupil's work and identify pupils needing support. Pupils were not confined to particular desks and often were rotated to join the front desk (closest to the teachers' desk) for focussed teaching, or were asked to work with the LSA in the side room. In our analysis of the activities within this environment we identified three themes of governance and self-governance; (i) not 'why' but 'what', (ii) follow the procedure, and (iii) make the right choice.

\section{Mechanisms of governance and self-governance}

Not 'why' but 'what'

In mathematics calculation choosing, and carefully following, the appropriate process to solve a sum is central to the production of a correct answer. This process structured the content of the lessons observed. A rationale for studying the calculations was not explicitly shared, other than the need to get sums and problems right. In this way the 'what' of the calculation structured the subject matter and governance in the lessons. The 'why', or contextual usefulness of such calculations, was subordinated to the need to be competent in the procedure of the calculation. Pupils were required to perform these procedures within tasks that correlated to testing conditions. This formed the implicit purpose of the requirement to be competent. 
Variation in acting out the prescribed procedures was provided via strategies such as pair sharing answers, working through prepared sheets of sums or by the teacher posing questions to the whole class. These strategies helped to identify who was obviously 'on' or 'off' task. Pupils were also required to publicly display 'yes' or 'no' decisions by standing, sitting or putting their hands on their heads. Asking such responses helped to determine if calculations had been completed correctly. If pupils could not answer a question publically, they were encouraged to 'bounce' it to another pupil as a means to find someone who was able to supply the correct answer. Focussing on the narrow outcome of the 'what' of the calculation required pupils to publically demonstrate who was 'right' and who was 'wrong'. Why a decision might be 'right' or 'wrong' was not explored, it was the rule to the calculation that was important; knowing the procedure, remembering it and using it to produce correct results.

Other ways of ensuring pupils evidenced their competence in calculation procedures was sought via written records in exercise books and worksheets. Exercise books were vitally important records of the pupils' competence in the 'what' of calculation. These written records were subjected to regular surveillance by the Senior Leadership Team (SLT) in the school. They were seen as evidence of staff diligence in ensuring pupils were secure in the stipulated curricula content and that any incompetence was being addressed. OfSTED also use exercise books for the same purpose. Each lesson started with the need for pupils to respond to the teachers' or LSAs' written comments in their books:

The LSA approaches Jason as he looks at his book.

LSA: "So Jason what did I write, I did write this is not a lot of work for two sessions of maths, remember to ask for help if needed. This really was not a lot was it, not for two sessions. No". LSA: "The biggest thing was I think you have got a bit mixed up. I understood your number sentences but here you have added instead of taking away..... think sometimes it is your setting out as well because this is all a bit jumbled, now this would have been OK and may be this not, if this bit of space is blank that's fine I would have put this over here (on next page) yes? Because it all looks a bit jumbled. So we did have a chat about it, why you did not get so much done so if we are in this position today I think you might be working with me. If there is a problem ask me OK? Right.

In this exchange the LSA first directed Jason to the quantity of work he had evidenced. Jason was reminded that his book constituted his commitment to his studies and was closely monitored. His contravention of the expectation to produce a sufficient quantity of work was significant enough for the LSA to remember and to make the special effort to reaffirm, in person, her disapproval. Here we see surveillance by OfSTED and the SLT being reproduced in the classroom with the same desired outcome; to generate pupils into selfgovernance to produce sufficient evidence of being secure in the 'what' of numeracy. Jason was also corrected in the way his work was ordered and spaced. The LSA decided this was the cause of him doing the wrong calculations. The current state of his book made it difficult for the marker to evidence her diagnosis and treatment of specific issues. As a consequence, Jason was clearly directed to follow the correct procedures for both the calculation and how to evidence his competence. 


\section{Follow the procedure}

The logic of calculation and testing pervaded the way the pupils were directed to work within the classroom. If unsure the pupils were directed to "if in doubt jot it out" to reduce mistakes in mental calculation. Ambiguity in what procedure to follow when calculating was avoided, particularly, when pupils were publically sharing their results:

The pupils are solving equivalent fraction sums on a sheet which is also displayed on the whiteboard. Teacher: "3, 2, 1 and stop. I am going pass the pen to somebody this morning, came in got straight down to work avoided chatting with Sam who he normally chats with, I am going to pass it to Jason. You've got to do the talking through. OK No.6 what did you do? It's all down to you come on Jason." Jason: "What I did is I times the 2 and I did half of 12 which is 6 and errm that's all I got."

Teacher: "Right OK so let's think about that why did you do half though? Did you look for a relationship?

Jason: "Umm."

Teacher: "What's the relationship here? See the denominators they have given us both"

Jason: "Times by 4 ?"

Teacher: "OK so you know that $3 \times 4$ gives you 12. If you times the bottom by 4 what should you times the top by?

Jason: "6?"

Teacher: "Oh!"

Jason: "3?"

Teacher: "Bounce it to somebody (turns to the class) what do you do?"

Molly "times by 4."

Teacher: (works through the calculation with Jason) "It's OK to make mistakes Jason sometimes.

You're going to pick one more number and Mrs. Steele will keep an eye on you while he does this one. Which number?"

Jason: "number 8"

Positive reinforcement of Jason's decision to make the right choice to be productive was shared publically and he was rewarded by being chosen to perform at the board. Clear instructions were given that his performance was vital and that it must be accompanied by a verbal commentary. Unfortunately, for Jason he was unsure of the correct procedure to follow. The chance to talk through his decision was cut short by the identification of his error by the teacher. Jason was required to be complicit in directing the class away from his continued misunderstanding, by having to choose someone who might know what to do. There was no space provided for the diagnosis of decision making. By tasking the LSA to check his work, potential space for repeating his error is also closed down; there is no escape from the all seeing eye of SATs and inspection. This example helps to illustrate how the correct procedures of calculation created the structure for the pupils' performances, especially when performing in front of the class.

The LSA was similarly very clear about directing the children to follow the correct procedure to meet the expectation to produce legible and logically displayed calculations:

A small group of 5 pupils are working through word problems which require addition and subtraction with the LSA in the side room.

LSA: (kneeling down by a small whiteboard on a stand) "0 takeaway 5 so what do we need to do?" Nathan: "Borrow?"

LSA: "Oh! We are not borrowing because we are not going to give it back! What's that other word?"

Lisa: "Exchanging?"

LSA: "Right so which column do I go to?"

The pupils talk through the process of exchanging to enable a subtraction to a positive number.

LSA: "9 take away 0" 


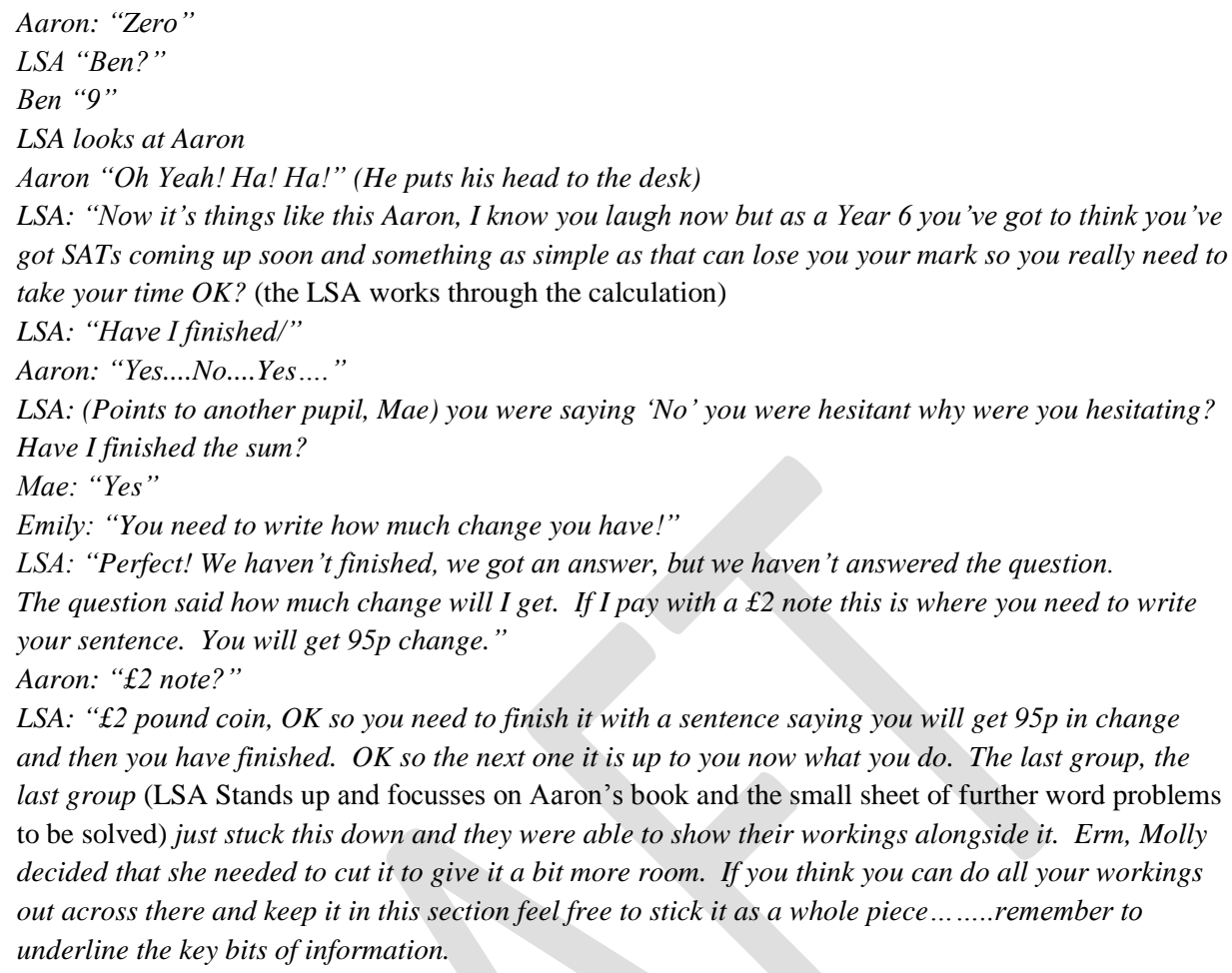

In this example it is possible to observe the reproduction of the discourses of test procedures; setting out work clearly for yourself and the marker, knowing the correct terminology and using a clear procedure to reach the correct answer. The purpose of the latter was to make sure a marker will be able to identify what has been interpreted from the question and that an answer had been reached. Aaron provided the LSA the opportune example of how simple errors can lead to missed marks and the need for pupils to pay close attention to the detail. The pupils were left in no doubt what terminology to use in subtraction and the correct procedure for answering a mathematical problem in the form of words. Any uncertainty was quickly dispelled. Within this discourse of certainty and precision, Aaron took the opportunity to remind the LSA that $£ 2$ note was not correct! When the pupils were set the task of completing word problems on their own, they were first directed to the importance of setting out their work to make sure there was enough room to display evidence of their written calculations. Whilst a choice was alluded to, in reality there was little to negotiate here; the pupils were given a clear procedure for setting out their work and deciphering and answering the questions set. How the pupils were to act was clearly articulated. The LSA was very explicit here in training the pupils to follow the procedure for maximising their success in evidencing their ability to calculate and to be right. The pupils were also being trained here to make the right choices when given space to make decisions. 


\section{Make the right choice}

When combined with the use of rhetorical questions, the positive reinforcement of making the 'right' choice served to direct pupils' actions toward 'good' habits. This funnelling of pupils into making the right choice also extended to decisions in what to do once the whole class teaching was moved to individual tasks:

Following on from the Jason's performance at the board:

Teacher: "now before we move on if there is anyone in the room is looking at that and thinking 'Nah talk me through it' pop on a table with Mrs. Steele even if it's for 5. Jason do you want to go? (Jason gets up out of his seat) yes good boy, anyone else? Hey you get a bit of private time, one to one" LSA: "Gail are you about to move? No? Yes? No? Yes."

Gail gets up from her seat to go to the side room.

Teacher: "Tom pop on hun that's what is about, OK. We are moving on in here."

Often the choices post whole class teaching involved working with the LSA, moving to the front desk to work with the teacher or choosing which worksheet to complete. In this example, a rhetorical question confirmed the right choice for Jason was to go to receive extra support and his correct actions are positively reinforced. Tom is not given a choice, however, Gail is publically encouraged to choose 'correctly'. Throughout the lessons observed the pupils demonstrated little resistance to work in the groups designated by the teacher and only on very rare occasions did pupils not respond as required to a rhetorical request to work specifically with the teacher or the LSA. Essentially, the pupils' self-governed themselves to ensure they responded to their identification by staff that they needed to demonstrate sufficient improvement and security in the calculations.

Positive reinforce of correct choices and thus good habits were employed to train the pupils to be self-governing in their clear display and precise following of procedures for calculations. The pupils were also clear in their duty to ensure they were correct in their productivity. For example:

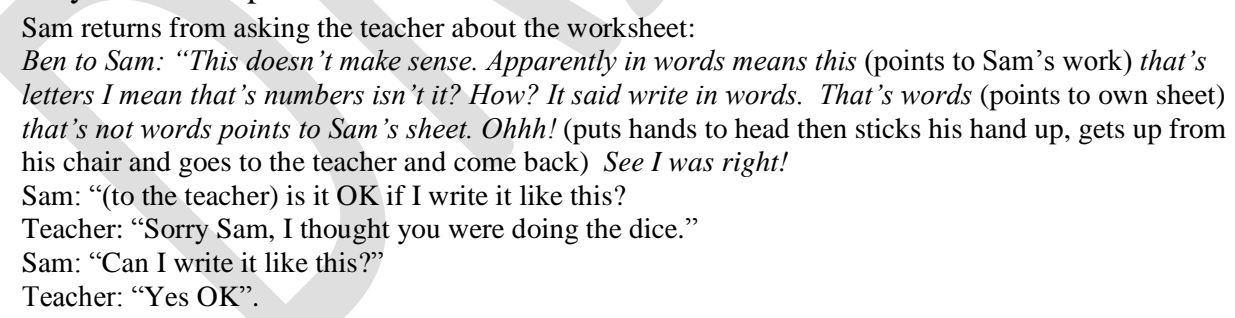

Being correct and following the right procedure required by a mathematical question was a strong feature in this example of self-governance. Both Sam and Ben were 'on task' and completing questions on the worksheet, however, Ben was conflicted by Sam's response that had been given credibility through his discussion to the teacher. However, the importance of following the correct procedure called into question the creditability of Sam's response. Both Sam's and the teacher's mistake are called out by Ben's self-governance in responding correctly to the question on the worksheet. In seeking approval to continue as before, Sam aimed to be right, even if he was wrong in relation to the worksheet. 


\section{Directions of governance and self-governance}

Our analysis suggests testing and inspection constitute a system of surveillance which pervades the micro governance of actions upon actions within the classroom. This provides the frame within which pupils were required to follow correct procedures, make right choices and publically evidence their competence in the 'what' of calculation. By analysing the spaces in which pupils and staff resisted these mechanisms of governance, we are also able say something about the directions of this governance. Resistance can work both against, but also in-line, with the direction of governance. In our in analysis of this resistance we identified two themes; (i) produce the correct answer to pass the test and (ii) being secure.

\section{Produce the correct answer to pass the test}

When pupils were asked to use a die to generate numbers to be calculated, some pupils chose to see how long they could get the die to spin before it stopped, or used a ruler to flick it against pencil cases to make it roll and stop. These unorthodox methods helped the pupils to delay their work, specifically, the need to produce the correct answer. We also saw more direct oppositional resistance against the direction of governance. Formalised surveillance was employed to ensure the production of correct answers was particularly notable in the weekly times table tests. Each week all the pupils sat a timetable test and their results were publically declared and recorded:

The pupils have been handed times table test papers and their score from the last test are read to be written on the top of the paper as a target for this test.

Teacher: "....Jason had bit of an off week last week but the week before you had a 90and a 17 so let's see if you can do that......Aaron 90 and 21 write it at the top that's what you are going to be........ve 81 I've got feeling you are going to get really close to 90.......Dan 55 I've got a feeling you are going to be in the 70s this week I can just feel it just get in the zone.......Emily 84 and 56 that's a good score. Right, I am going to put the timer up on the board. Any tips? Cos we are doing these but what tips have you got? (Hand go up) Aaron? Aaron: "Get your head down"

Teacher: "Definitely focus, go on (looks at Ellie)"

Ellie: "If you have not, like, done not all questions on one page then instead of going to the other side try and answer the question that you missed out."

Teacher: "Yeah we are going to try and get all 90 on one page before we move on. Good."

Emily: "Make sure you are accurate and not just rushing through too fast."

Teacher: "Definitely that will affect your focus. Any sneaky tricks? Like, anyways we can remember them? James (defers to James who's hand it up)

James: "Well for the 8 s I just remember them as 2 times down from four and 2"

Teacher: "Great so you use your 2 timetable and you double it and double it again what a great way. Ok so if it was $2 \times 8,2 \times 2$ is 4 and you double it and double again. Michael?"

Michael: "I've done the first 3 already and get them in my mind and then as soon as it goes I write them out and I am off."

Another pupil "Yeah that's what I do."

Teacher: "Can anyone remember erm what it if I ate and ate I am sick on the floor?"

John: "That's $8 \times 8$ is 64."

Teacher: "Very good that's one of them if $8 x 8$ is on there think of that one. What about $7 \times 8$ or $8 \times 7$ how do we remember that one? (looks at Ruby) go on."

Ruby: "56 5, 6, 78 ..."

Teacher: "Here we go 6 minutes going on the board have a scan already, you know if it's the 11 timetable you've got that one, 2, 5, 10s, 11 you've got those. The ones to think about are your 6,7 and $8 s$ and go from there. Good luck go." 
We can see here how the direction of governance to pass the test, worked with the mechanism of following the right procedure. It was an expectation that the pupils would improve each week. High scores were noted and pupils close to obtaining full marks were urged to aim for full marks. The wrapping of positive predictions softened the stark public sharing of low scores from the previous week. When asked about performance tips, the pupils directed the discourse to being productive. The teacher steered this discussion towards memorising strategies which also served to continue the focus upon producing the correct answers to pass the test. These scores were then shared publically, for example:

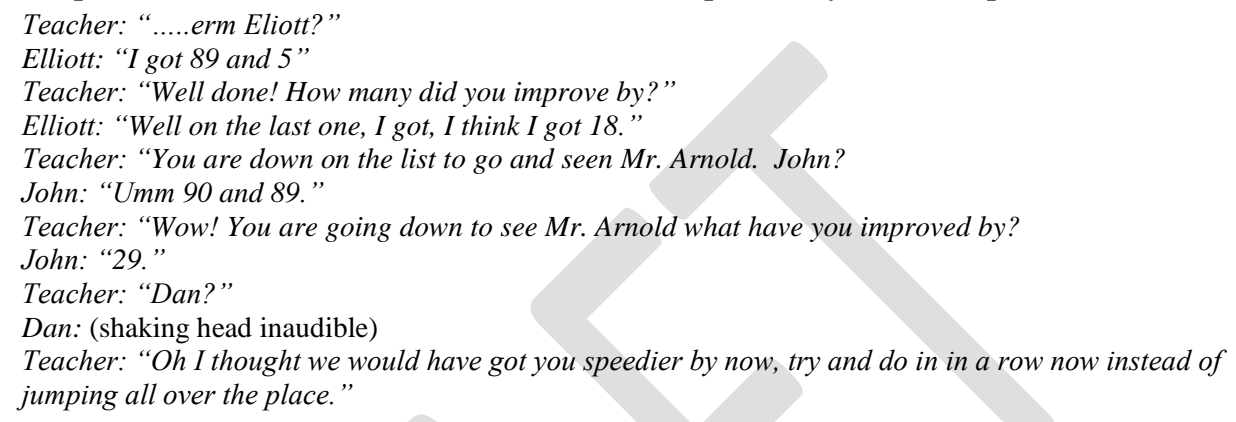

In this example of public personal performance review, we can see the performativity of school SATs results being clearly reproduced in both the direction and mechanism of governance. The direction to produce correct answers in this case was reinforced by the requirement to publically declare test scores. Non-improvement was softened slightly by 'tips' for next time, whereas, those identified as having improved sufficiently, were listed to see the headteacher. In doing so, a chain of obligation was brought into the classroom. The teacher used her accountability to the headteacher to positively reinforce the performance of those who made the right choice. The choice to memorise and demonstrate continual improvement in knowing their times tables under test conditions. Such choices identified security in possessing the requisite tools to complete calculations and the discipline required to sit a test.

\section{Being secure}

The repetition of completing calculations appeared crucial to becoming secure in the 'what' of the mathematics studied. Pupils were required to self-assess this security by completing a formalised 'What we are Learning Today' (WALT) sheet which was handed out at the start of every lesson. Some pupils resisted directly by not completing these forms, which was subsequently picked up when books were marked. Other more direct resistance in being secure was observed in cases when pupils, who had offered incorrect answers in whole class teaching, refused directly the suggestion to work with the LSA. In returning to the example of Jason unsuccessfully working through an equivalent fraction at the board, we also observed resistance that was in-line with the need to be secure. By coming to the board and producing the wrong answer in public Jason resists 'being secure', however, concurrently, he ensures that he will get to the right answer and become secure. Some pupils also used spaces to negotiate the tools they employed to solve problems: 
The pupils have been working on equivalent fractions in the first session and return after break. When settled the teacher begins.

Teacher: "My question is, it's a big decision in life, especially for me because say I could have $\frac{6}{12}$ of a Galaxy bar (chocolate bar) or I could have $\frac{3}{12}$ of a galaxy bar. I need you to make sure that I obviously get the most chocolate, the largest amount. Talk, talk to your partner which one would I get the most galaxy?"

A noisy discussion ensues amongst neighbours and tables in the classroom. Eloise reaches for a post-it note in the stationary tray on her desk. Her partner watches and also debates with a boy sitting opposite. Eloise draws out 2 graphic representations of chocolate bars on her post-it note. She divides one into 6ths and one into 12 ths

Teacher: "3, 2, 1, any thoughts? Which one should I go for?"

The teacher chooses some pupils with hands up. Meanwhile Eloise realises that scale drawing is very important when working out the problem. She crosses out her second chocolate bar to make it the same size as her first. She shades in $\frac{3}{6}$ and $\frac{6}{12}$

Teacher: "Maddie?"

Maddie: "You could go for either of them"

Teacher: "Ok I will come back to you, anyone else $\frac{3}{6}$ or $\frac{6}{12}$ ?"

Other pupils are chosen who reason the $\frac{6}{12}$

Teacher: "Tom?"

Tom: "They are exactly the same!"

Teacher: "My question was does anyone think, thanks for sharing that, anyone else think $\frac{6}{12}$, Amy?"

Amy: "The same amount but you get more pieces with $\frac{6}{12}$."

Eloise confers her answer with her partner and they nod in agreement.

Teacher: "Who can explain, it doesn't matter which one, who can explain why you would get the same amount?"

Eloise puts her hand up and is chosen

Eloise: "I drew two chocolate bars the same size and split one into 6ths and this one into 12 pieces.

Say I ate 3 of the $6 s$ and gave the rest to Sam (her partner) and I did the same with the other one it tells me they are the same amount."

Teacher: "Have a house point, well done for jotting it down. So factions can have the same remunerator and the same denominator but also be the same. This is what we are going to do now, find them and name them. Let's work through some examples."

Eloise demonstrated her resistance to using the calculation procedure she had been studying in the first session of the morning, by favouring her own graphic method to solve the problem. Maddie and Tom had followed this direction of governance and demonstrated they were secure in the numerical calculation required to test equivalence. The teacher also seemed to resist the direction to produce correct answers by ignoring these responses. In abruptly admitting the amounts of chocolate are actually the same, the pupils were then directed to being secure in their understanding of equivalence by reasoning why they are the same. By chance Eloise managed to share her reasoning, however, this did not represent being 'secure' in the procedures being taught. She was rewarded for 'jotting out', but her solution was swept to one side in favour of being secure in the correct procedure to find equivalent fractions through numerical calculation.

\section{Discussion of teacher and pupil subjectivies}

In this study we are able to draw clear parallels between primary school classroom governance and Ball's (2003) theorising of school and teacher performativity. However, our analysis also enables us to say something about the co-constitutive teacher and pupil subjectivities. Our findings demonstrate how surveillance through the metrics of 
performativity, SATS and potential inspection by the SLT and OfSTED, constituted the governance and self-governance within this classroom. Whilst not all the learning activities took the overt form of a test, most were in effect tests in disguise, either in being required to publically perform the correct procedure, or to answer homework and class worksheets correctly. This structuring of tasks subordinated the 'why' of mathematical calculation into repetition of the 'what' of calculation. Success in producing correct answers required pupils to make the right choices to follow the designated procedures.

The pupils needed to be unafraid to make mistakes and accept the requirement to work to improve and become secure in calculation. Displays of incompetence or insecurity in calculation functioned to ensure they would receive support to fulfil their role to perform correctly. The forthcoming nature of this support helped to shape the pupils into becoming self-governed workers, complicit in the need to produce sufficient quality evidence that could be easily scrutinised in public or in their books. Therefore, whilst the pupils were required to be linear, progressive and functional (Llewellyn, 2015) their actual subjectivity was that aligned to being 'Confessant and unafraid producers of evidence'. This was able to emerge within a notably safe environment where potential shame and retribution for mistakes was minimised. The teachers and pupils were thus complicit in creating sufficient space for everyone to fulfil their obligation to be accountable to the SLT, OfSTED and SATs; the pupils to 'produce' evidence and the staff to become 'Evidence hunters'.

In contrast to the conflicted teacher subjectivies explored by Walshaw (2013), the LSA was quite clear in her realisation of evidence hunter within this system of surveillance. She clearly privileged the production of evidence and made clear to pupils their responsibilities to produce the right evidence in the right format. In doing so, her role to support the pupils in this production process was made explicit; identifying success, misunderstandings and pointing out where lax adherence to procedures had led to mistakes. This close alignment of the LSA's subjectivity to testing and inspection discourses provided little ground for ambiguity and negotiation by the pupils. In this way the two subjectivities were mutually supportive.

Whilst it was clear the teacher in our study was also hunting for evidence to enhance the performativity of the pupils, there were instances of attempts to soften the directions and mechanisms of the governance. This contrasts with Ball's (2003) suggestion of teachers abandoning their personal values and the findings of Bob (2002) who reported clashing between emotionally caring, humanistic discourses and the hard reality of preparing pupils to perform in national tests. We observed more nuanced negotiation where, for example, the teacher often placated potential shame in being wrong by suggesting it was "OK to make mistakes" as long as this was "sometimes". Pupils were thanked and rewarded for their contributions, even if they were not the model answers which were being sought. Similarly, pupils' rare public decisions not to go for extra help were respected. Poor results were parcelled with encouraging and positive language and although very narrow in nature, the teacher also aimed to provide choices. These subtle attempts to mediate between surveillance 
through testing and inspection and her emotional care for the pupils created a more layered subjectivity of evidence hunting than that of the LSA.

The chocolate bar problem, for example, gave the pupils' study of equivalent fractions some rarely provided contextual meaning. In doing so, the teacher alluded to a brief notion of fostering 'enquiring' pupil subjectivity (Llewellyn, 2015). This opened up space for negotiation in how to solve the question. Tom and Maddie's swift and correct contributions, however, were ignored in favour of the teachers' own resistance to the governance. Tom and Maddie had to demonstrate self-governance in following the procedure to allow the teacher to hunt for the evidence she required. Unlike the unequivocal subjectivity of 'evidence hunter' adopted by the LSA, this example indicates the added complexity for pupils created by the teachers' own negotiation of surveillance via testing and inspection. These findings help to move beyond proving the existence of a panoptic metaphor to reveal the co-constituting development of staff and pupils' subjectivities (Gallagher, 2010).

\section{Conclusions}

Our findings help to contribute classroom level detail to Ball's (2003) theorising of how national testing shapes 'who' teachers are to 'be', what learning 'is' and how 'it' is to be done. By exploring the realisation of direct lines of accountability within classroom governance, we are able to enrich the perspectives of primary teachers reported by Keddie (2017) and reveal the consequences for the relations between teachers, pupils and subjectmatter. In doing so we are able to reveal the subtle differing subjectivies between staff and those of the pupils. These are often separated when examining the consequences of national policy. Our findings illustrate the consequences for pupils and teachers when government policy privileges the achievement and evidencing of measurable skills, above the possibilities for the study of subject-matter to support intellectual development (Clements, et al., 2013). In particular, we are able to indicate the significance for pupils and teachers of the logical linear, progressive child of English mathematics policy by revealing the additional need for pupils to 'produce' and teachers to 'hunt' for evidence of their attainment (Llewellyn, 2016). These findings help to illustrate the consequences of curricula outcomes couched in the individualisation of the performance of mathematical knowledge within the classroom (Ball, 2013; Brown, 2008). In our study mathematical knowing was constituted as a discipline of reproducing testable calculation. As a result, mathematical creativity or any development of mathematical curiosity appeared to be killed off by the all seeing eye of SATS, the SLT and OfSTED.

Ball (2013) demonstrates how testing and inspection divides the flesh and blood of those whose lives it aims to change. In this study we observed how mathematical knowing under SATs and inspection equated to the division of pupils who were 'correct' and those who were 'wrong'. In order for this separation to have authority and thus creditability, Pais (2016) argues, success in SATs simply results in more difficult tests. Therefore, using high stakes testing as a means to guarantee that all pupils at some point will be deemed successful is implicitly contradictory (Pais, 2016). Greater awareness of the consequences of testing and inspection upon pupil and teacher subjectivities may support more informed negotiation of 
national policy. This is particularly important when limited ways of knowing within a subject are exposed. The need for continued critical research remains high as it through such studies that broader ways of knowing may be negotiated within the current policy landscape.

\section{References}

Alexander, R. (2011) Culture and pedagogy: International comparisons, Oxford: Blackwell.

Azzarito, (2009) The Panopticon of physical education: pretty, active and ideally white, Physical Education and Sport Pedagogy,14(1), 19-39.

Ball, S. (2003) The teacher's soul and the terrors of performativity, Journal of Education Policy, 18(2), 215-228.

Ball, S. (2013) Foucault power and education, Abingdon: Routledge.

Biesta, G. (2008) What kind of citizen? What kind of democracy? Citizenship education and the Scottish Curriculum for Excellence, Scottish Educational Review, 40 (2), 38-52.

Blackford, H. (2004) Playground panopticism: Ring-around-the-children, a pocketful of Women. Childhood, 11(2), 227-249.

Boaler, J. (2015) The elephant in the classroom: Helping children learn and love maths. Souvenir Press: London.

Bob, J. (2002). Performativity and primary teacher relations, Journal of Education Policy, 17(5), 531-546.

Booher-Jennings, J. (2008) Learning to label: socialisation, gender, and the hidden curriculum of high-stakes testing, British Journal of Sociology of Education, 29(2),149-160.

Burnitt, M. (2016) Primary Headteachers: Perceptions on Standards, Accountability and School Context, unpublished Ed.D thesis: Institute of Education.

Brown, T. (2008) Lacan, subjectivity and the task of mathematics education research, Studies in Educational Mathematics 68(2) 227-245.

Bryman, A. (2008) Social research (3rd Edition), Oxford: Oxford University Press

Carmichael, C. and MacDonald, A. (2016) Parental influences on primary school children's mathematics achievement: insights from the Longitudinal Study of Australian Children, Education 3-13, 44(2), 197-211.

Clements, M., Bishop, A., Keitel-Kreidt, C., Kilpatrick, J., Leung, F.K.-S. (2013) From the few to the many: Historical perspectives on who should learn mathematics, In M. Clements, A. Bishop, C. Keitel-Kreidt, J. Kilpatrick, F.K.-S Leung, (Eds.) Third international book of mathematics education, Springer-Verlag: New York, 7-40. 
Connell, R. (2009) Good teachers on dangerous ground: Towards a new view of teacher quality and professionalism, Critical Studies in Education, 50(3), 213-229.

Courtney, S. (2016) Post-panopticism and school inspection in England, British Journal of Sociology of Education, 37(4), 623-642.

Davies, B. (2017) Life in the classroom and playground: Accounts of primary school children, Routledge: Abingdon.

Department for Education (2013) The national curriculum in England: Mathematics programme of study. Available at: https://www.gov.uk/government/publications/nationalcurriculum-in-england-mathematics-programmes-of-study/national-curriculum-in-englandmathematics-programmes-of-study

Department for Education (2017) Information for parents: 2017 national curriculum tests at the end of key stages 1 and 2, Standards and Testing Agency, available at:

https://www.gov.uk/government/publications/2017-national-curriculum-tests-for-key-stages1-and-2-information-for-parents, accessed: June, 2017.

Elden, S. (2003) Plague, panopticon, police, Surveillance and Society, 1(3), 240-253.

Epstein, D., Mendick, H. and Moreau, M-P. (2010) Imagining the mathematician: young people talking about popular representations of maths, Discourse: Studies in the Cultural Politics of Education, 31(1), 45-50.

Ernest, P. (2016) The problem of certainty in mathematics, Educational studies in Mathematics, 92(3), 379-393.

Hammersley-Fletcher, L. (2002) Becoming a Subject Leader: what's in a name, School Leadership and Management, 22(4), 407-420.

Falabella, A. (2014) Do national test scores and quality labels trigger school self-assessment and accountability? A critical analysis in the Chilean context, British Journal of Sociology of Education, 37(5), 743-760.

Foucault, M. (1977/1995) Discipline and Punish: The Birth of the Prison. Vintage Books: New York.

Foucault, M. (1982) The subject and power, Critical Enquiry, 8(4), 777-795.

Foucault, M. (1987) The ethic of care for the self as a practice of freedom: an interview with Michel Foucault on January 20, 1984. In: Fornet-Batancourt, R, Becker, H. GomezMüller, A. and Gauthier, J. (1987) Philosophy and Social Criticism 12(2/3), 112-131.

Gallagher, M. (2010) Are school panoptic? Surveillance and Society 7(3/4), 262-272.

Hardy. I. and Lewis, S. (2016) The 'doublethink' of data: educational performativity and the field of schooling practices, British Journal of Sociology of Education, i-first article available at: http://dx.doi.org/10.1080/01425692.2016.1150155 
Hill, D., Lewis, C., Maisuria, A., Yarker, P. and Hill J. (2016) Conservative education reloaded: Policy, ideology and impacts in England, Journal for Critical Education, 14(3), 142 .

Hodgen, J. and Askew, M. (2007) 'Emotion, identity and teacher learning: becoming a primary mathematics teacher', Oxford Review of Education, 33(4) pp.469-487.

Hodkinson, P., Biesta, G. and James, D. (2007) Understanding learning cultures, Educational Review, 59(4): 415-27.

Houssart, J. and Barber, P. (2014) Eliciting pupil perspectives in primary mathematics: possibilities and issues, Education 3-13, 42(6), 648-662.

Jones, H. (2010) National Curriculum tests and the teaching of thinking skills at primary schools: Parallel or paradox? Education 3-13, 38(1), 69-86.

Keddie, A. (2017) Primary school leadership in England: Performativity and matters of professionalism, British Journal of Sociology of Education, i-first article, available at: http://dx.doi.org/10.1080/01425692.2016.1273758

Kollosche (2014) Mathematics and power: an alliance in the foundations of mathematics and its teaching, ZDM Mathematics Education, 46(7), 1061-1072.

Lingard, B., Martino, W. and Rezai-Rashti, G. (2013) Testing regimes, accountabilities and education policy: Commensurate global and national developments, Journal of Education Policy, 28(5), 539-556.

Llewellyn, A. (2016) Problematising the pursuit of progress in mathematics education, Educational Studies in Mathematics, 92(3), 299-314

Mandell, N. (1998) The least-adult role in studying children, Journal of Contemporary Ethnography, 16(4), 433-467.

McEvoy, E., Enright, E. and MacPhail, A. (2015) Negotiating 'ethically important moments' in research with young people: reflections of a novice researcher, Leisure Studies, 36(2), 170-181.

Mead, M. (1928]/2001) Coming of Age in Samoa: A Psychological Study of Primitive Youth for Western Civilisation. Harper Perennial Modern Classic: New York.

Mendick, H. (2005) A beautiful myth? The gendering of being/doing 'good at maths', Gender and Education, 17(2), 203-219.

Mistry, M. and Krishan, S. (2015) Why are there still so few men within Early Years in primary schools: views from male trainee teachers and male leaders?, Education 3-13, 43(2), $115-127$

Muijs, D. and Reynolds, D. (2000) School Effectiveness and Teacher Effectiveness in Mathematics: Some Preliminary Findings from the Evaluation of the Mathematics 
Enhancement Programme (Primary), School Effectiveness and School Improvement, 11(3), 273-303.

Newman, E. and Foster, V. (2005) Just a knock back? Identity bruising on the route to becoming a male primary school teacher, Teachers and Teaching: Theory and Practice, 11 (4), 341-358.

Öhman, M., and Quennerstedt, M. (2012) Observational Studies. In K. Armour and D. Macdonald (Eds) Research Methods in Physical Education and Youth Sports, London: Routledge, 189-203.

O'Leary, M. (2012) Surveillance, performativity and normalised practice: The use and impact of graded lesson observations in further education colleges, Journal of Further and Higher Education, 37(5), 694-714.

Ozga, J. (2009) Governing education through data in England: from regulation to selfevaluation, Journal of Educational Policy, 24(2), 49-162.

Pais, A. (2016).The narcissism of mathematics education. In H. Straehler-Pohl, N.

Bohlmann and A. Pais (Eds.) The disorder of mathematics education. Springer International Publishing: Cham, Switzerland, 53-63.

Perryman, J. (2002) Surviving special measures: A case study of a fresh start school, Improving Schools, 5(3), 46-59.

Perryman, J. (2006) Panoptic performativity and school inspection regimes: Disciplinary mechanisms and life under special measures, Journal of Education Policy, 21(2), 147-161.

Puurveen, L., Phinney, A., Cox, S. and Purves, B. (2015) Ethical considerations in the use of video observations in dementia end-of-life care research, In D. Warr, M. Guillemin, S. Cox and J. Waycott (Eds.) Ethics and Visual Research Methods, Palgrave Macmillan: New York, 105-11.

Rabinow, P. (1984) (Ed) The Foucault Reader. Pantheon Books; New York.

Randell, (2012) Revisiting Mandell's 'least adult' role and engaging with children's voices in research, Nurse Researcher, 19(3), 39-43.

Richards, C. (2008) Educational inequality in English primary education, Education 3-13, 36(4), 365-370.

Robson, S. (2011) Producing and using video data in the early years: Ethical questions and practical consequences in research with young children, Children and Society, 25, 179-189.

Rose, N. (1998) Governing risky individuals: The role of psychiatry in new regimes of control, Psychiatry, Psychology and Law 5(2), 117-95.

Segal, A., Snell, J. and Lefstein, A. (2016) Dialogic teaching to the high-stakes standardised test? Research Papers in Education, i-first article, available at: http://dx.doi.org/10.1080/02671522.2016.1225803 
Tavory, I. and Timmermans, S. (2014) Abductive analysis: theorising qualitative research, University of Chicago Press: Chicago.

Teague, L. (2014) Subjectivity, agency and political pedagogy in the primary school, Global Studies of Childhood, 4(1), 3-10. 
Thomas, S. Gana, Y. and Muňoz-Chereau, B. (2016) England: The intersection of international achievement testing and educational policy development, in L. Volante (ed) The intersection of international achievement testing and educational policy development: Global single perspectives from large scale reform, Routledge: Abingdon, 37-46.

Tseng, C. (2015) Changing headship, changing schools: How management discourse gives rise to the performative professionalism in England (1980s-2010s), Journal of Education Policy, 30(4), 483-499.

Walkerdine, V. (1989) Counting girls out. London: Virago Press.

Walkerdine, V. (1990) Schoolgirl fictions. London: Verso.

Walshaw, M. (2013) Post-structuralism and ethical practice action: Issues of identity and power, Journal for Research in Mathematics Education, 44(1), 100-118.

Webb, T., Briscoe, F. and Mussman, M. (2009) Preparing teachers for the neoliberal panopticon, Educational Foundations, Summer-Fall, 3-16.

Whiting, R., Symon, G., Roby, H., and Chamakiotis, P. (2016) Who's behind the lens? A reflexive analysis of roles in participatory video research, Organizational Research Methods, i-first article available at: https://doi.org/10.1177/1094428116669818

Wilkins, M. (2015) The tyranny of no alternative: co-operating in a competitive marketplace, International Journal of Inclusive Education, 19(11), 1172 